\title{
An enhancer peptide for membrane-disrupting antimicrobial peptides
}

Satoshi Ueno ${ }^{1,2 \dagger}$, Kohtaro Kusaka ${ }^{1 \dagger}$, Yasushi Tamada ${ }^{1}$, Hong Zhang ${ }^{1}$, Masaomi Minaba', Yusuke Kato ${ }^{1 * \dagger}$

\begin{abstract}
Background: NP4P is a synthetic peptide derived from a natural, non-antimicrobial peptide fragment (pro-region of nematode cecropin P4) by substitution of all acidic amino acid residues with amides (i.e., Glu $\rightarrow$ Gln, and Asp $\rightarrow$ Asn).

Results: In the presence of NP4P, some membrane-disrupting antimicrobial peptides (ASABF- $\alpha$, polymyxin B, and nisin) killed microbes at lower concentration (e.g., 10 times lower minimum bactericidal concentration for ASABF- $\alpha$ against Staphylococcus aureus), whereas NP4P itself was not bactericidal and did not interfere with bacterial growth at $\leq 300 \mu \mathrm{g} / \mathrm{mL}$. In contrast, the activities of antimicrobial agents with a distinct mode of action (indolicidin, ampicillin, kanamycin, and enrofloxacin) were unaffected. Although the membrane-disrupting activity of NP4P was slight or undetectable, ASABF- $\alpha$ permeabilized $S$. aureus membranes with enhanced efficacy in the presence of NP4P.
\end{abstract}

Conclusions: NP4P selectively enhanced the bactericidal activities of membrane-disrupting antimicrobial peptides by increasing the efficacy of membrane disruption against the cytoplasmic membrane.

\section{Background}

Antimicrobial peptides (AMPs) are peptides that are selectively toxic against microbes. To date, more than 800 AMPs have been discovered in various organisms including vertebrates, invertebrates, plants, protozoans, and microbes. The structures of AMPs are extremely diverse. They are categorized into distinct structural groups such as amphipathic $\alpha$-helical peptides, and $\beta$ sheet peptides stabilized by intramolecular disulfide bridges [1]. Several AMPs are already in practical use. For instance, nisin is a widely used food-preservative in more than 50 countries including the United States of America, and countries within the European Union [2]. Polymyxin B has been used as a clinical antibiotic for more than half a century [3]. Many AMPs have also been investigated for practical use [4]. Microbial killing by AMPs is often correlated mainly with membrane disruption although some other intracelluar and extracellular mechanisms also contribute to overall activity [1].

\footnotetext{
*Correspondence: kato@affrc.go.jp

† Contributed equally

'Division of Insect Sciences, National Institute of Agrobiological Sciences, Oowashi 1-2, Tsukuba, Ibaraki 305-8634, Japan
}

Several AMPs such as indolicidin attack intracellular targets without membrane disruption [5].

Using combinations of agents is common in a clinical setting in order to obtain more effective antimicrobial properties. Such combinatorial application is also effective for AMPs. Conventional low-molecular-mass antimicrobials often exhibit synergistic effects with AMPs [6]. Synergy is also observed in some combinations of AMPs naturally coexisting in the tissues of producing organisms, e.g., magainin 2 and PGLa [7], different isomers of dermaseptins and temporins [8,9], cathelicidins and defensins [10], $\beta$-defensin and BPI [11], hepcidin and moronecidin [12], Cg-Prp and Cg-Def [13], and AFP and sarcotoxin IA [14]. Certain artificial combinations of AMPs isolated from distinct organisms are synergistic, e.g., some eukaryotic AMPs and bacteriocins [15], and magainin and tachyplesin I [16]. Lysozymes, $1,4-\beta-N$-acetylmurmidases with membrane-perturbing activity, are synergistic with many AMPs $[17,18]$. The staphylococcal glycylglycine endopeptidase lysostaphin is also synergistic with polymyxin B and ranalexin $[19,20]$. All synergies mentioned above are found in combinations of AMPs and other antimicrobials including AMPs.
Ciomed Central

C 2010 Ueno et al; licensee BioMed Central Ltd. This is an Open Access article distributed under the terms of the Creative Commons Attribution License (http://creativecommons.org/licenses/by/2.0), which permits unrestricted use, distribution, and reproduction in any medium, provided the original work is properly cited. 
Here, we describe potent enhancement of AMP activities by a synthetic peptide NP4P (Y. Kato, K. Kusaka, S. Ueno, H. Zhang, and M. Minaba, 8 May 2008, Japanese Patent Office). Increase in positive charge facilitates the interaction of peptides with negatively charged biological membranes, and often results in the conferring of membrane-disrupting or membrane-penetrating activities. We generated some peptides derived from natural nonantimicrobial sequences, with modification to confer a cationic net charge. These peptides were then subjected to screening for novel AMPs that have structures distinct from those of known AMPs. NP4P was originally one of these peptides. The parent peptide of NP4P was a non-antimicrobial peptide fragment, nematode cecropin P4 pro-region (P4P, calculated pI = 5.80) $[21,22]$. NP4P was generated from P4P by substitution of all acidic amino acid residues with amides (i.e., Glu $\rightarrow$ Gln, and Asp $\rightarrow$ Asn), resulting in a reduction of negative charge and an acquisition of stronger net positive charge (Figure 1). It consisted of 30 amino acid residues and was highly basic (calculated $\mathrm{pI}=12.30$ ). When evaluating the pharmacological properties of NP4P, we found that NP4P enhanced the activities of some AMPs whereas no antimicrobial activity was detected for NP4P alone, suggesting that the effect of NP4P was an enhancement, but not a synergy as mentioned above. This study is the first report on the unique features of NP4P.

\section{Results and Discussion}

\section{Evaluation of antimicrobial activity of NP4P}

Antimicrobial activity was evaluated as the first step in pharmacological characterization of NP4P. We did not detect antimicrobial activity for NP4P at $\leq 300 \mu \mathrm{g} / \mathrm{mL}$ in growth-inhibitory and microbicidal assay against certain Gram-positive bacteria (Staphylococcus aureus IFO12732, Bacillus subtilis IFO03134, and Micrococcus luteus IFO 12708); Gram-negative bacteria (Pseudomonas aeruginosa IFO3899, Salmonella typhimurium IFO13245, Serratia marcescens IFO3736 and Escherichia coli JM109); and yeast (Saccharomyces cerevisiae MAFF113011), as well as against monkey Vero kidney cells (data not shown). In addition, NP4P $(300 \mu \mathrm{g} / \mathrm{mL})$ did not affect the growth curves of S. aureus IFO12732 (Figure 2A) and E. coli JM109 (Figure 2B). These results indicate that NP4P was less toxic to microbes.

\section{Enhancer activity for antimicrobial peptides}

The parent peptide P4P inhibited the bactericidal activity of cecropin P4 and some other antimicrobial peptides ([22]; S. Ueno and Y. Kato, unpublished data), encouraging us to test whether NP4P affected the activities of other antimicrobial agents. We examined the effect of NP4P on the bactericidal activities of the nematode CS $\alpha \beta$-type cationic AMP ASABF- $\alpha$ [23-25] against $S$. aureus IFO12732 (Figure 3A) and polymyxin B against E. coli JM109 in $10 \mathrm{mM}$ Tris- $\mathrm{HCl}, \mathrm{pH} 7.4$ (Figure 3B). Unexpectedly, NP4P enhanced these activities at $\geq 5 \mu \mathrm{g} / \mathrm{mL}$ in a dose-dependent manner. The dose-effect curves of ASABF- $\alpha$ and polymyxin B were shifted to almost 10 times lower concentration in the presence of $100 \mu \mathrm{g} / \mathrm{mL}$ NP4P. However, the enhancement was completely abolished in a high ionic strength condition $(150 \mathrm{mM} \mathrm{NaCl}, 50 \mathrm{mM} \mathrm{NaHCO} 3,10 \mathrm{mM}$ Tris- $\mathrm{HCl}, \mathrm{pH}$ 7.4).

Furthermore, we tested NP4P enhancement at $20 \mu \mathrm{g} /$ $\mathrm{mL}$ for the activities of antimicrobial agents against various microbes (Table 1). The results can be summarized as: (1) The bactericidal activities of all tested membrane-disrupting AMPs (ASABF- $\alpha$, polymyxin $B$, and

\section{Nematode cecropin P4 pro-piece (P4P)}

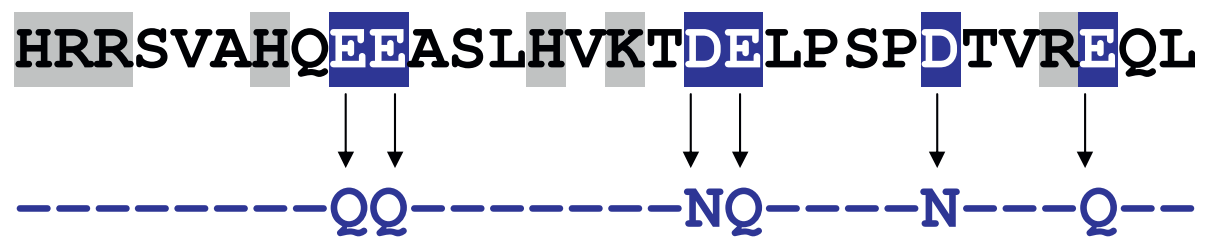

\section{Neutralized nematode cecropin $P 4$ pro-piece}

$$
\text { (NP4P) }
$$

Figure 1 Structure of NP4P. The parent peptide, nematode cecropin P4 pro-piece (P4P), is shown at the top. Inversed letters indicate acidic amino acid residues which were substituted with amides in NP4P. Letters on a grey background represent basic amino acid residues. 


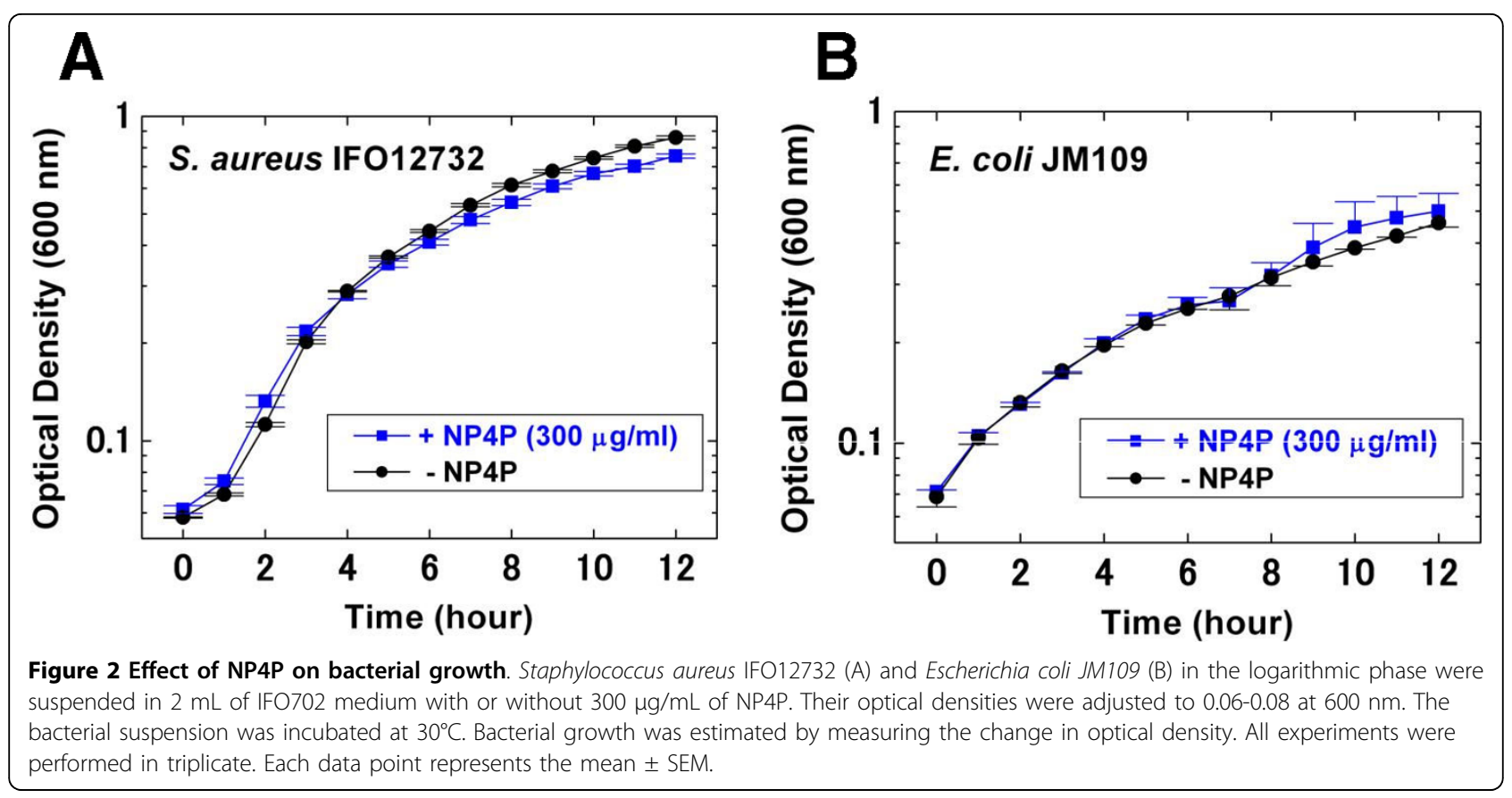

nisin) were enhanced. (2) The enhancement was selective depending on the type of bacterial species. For instance, the activities of ASABF- $\alpha$ against $S$. aureus IFO12732 and E. coli JM109 were enhanced, whereas a lesser enhancement was observed against $M$. luteus IFO 12708, B. subtilis IFO3134, P. aeruginosa IFO3899, and $S$. marcescens IFO3736. (3) NP4P did not enhance the activity of one AMP indolicidin which killed bacteria by inhibition of DNA synthesis and not by membrane disruption [5]. (4) NP4P did not affect the activities of conventional antimicrobial agents that do not target bacterial cytoplasmic membranes (ampicillin, kanamycin, and enrofloxacin).

Effect on disruption of the cytoplasmic membrane NP4P enhancement was observed only for the antimicrobial activities of membrane-disrupting AMPs. The simplest hypothesis accounting for NP4P enhancement was direct facilitation of membrane disruption. To test this hypothesis, we examined the effect of NP4P on the

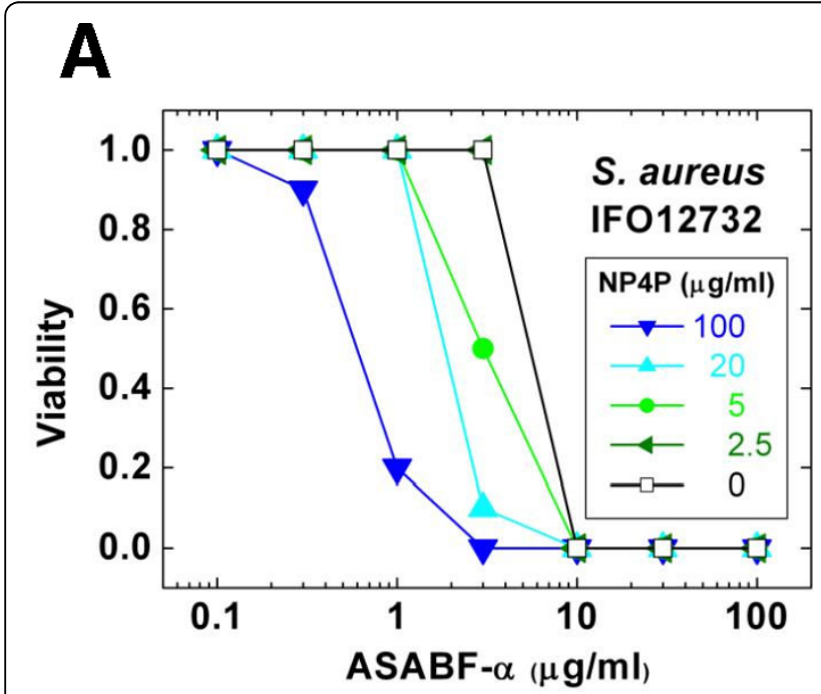

\section{B}

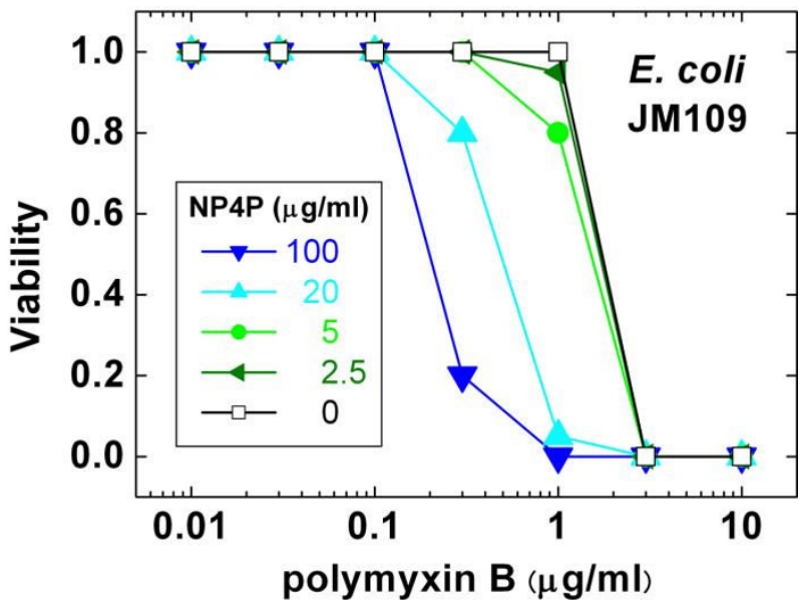

Figure 3 NP4P enhancement of bactericidal activities of AMPs. The dose-effect curves were determined in the presence of NP4P at various concentrations $(0,2.5,5,20$, and $100 \mu \mathrm{g} / \mathrm{mL})$. Bactericidal activities were measured against S. aureus IFO12732 for ASABF- $\alpha$ (A) and against E. coli JM109 to polymyxin B (B). Viability is defined as normalized number of viable cells to the number in the absence of ASABF- $\alpha$ or polymyxin B. 
Table 1 Effect on MBC values of various antimicrobial agents

\begin{tabular}{|c|c|c|}
\hline & \multicolumn{2}{|c|}{$\mathrm{MBC}(\mu \mathrm{g} / \mathrm{mL})$} \\
\hline & NP4P- ${ }^{a}$ & NP4P+ \\
\hline \multicolumn{3}{|l|}{ ASABF- $\alpha^{b}$} \\
\hline Staphylococcus aureus IFO12732 & 3 & 0.3 \\
\hline Micrococcus luteus IFO12708 & 5 & 2 \\
\hline Bacillus subtilis IFO3134 & 8 & 3 \\
\hline Escherichia coli JM109 & 3 & 0.3 \\
\hline Pseudomonas aeruginosa IFO3899 & 5 & 2 \\
\hline Salmonella typhimurium IFO13245 & 3 & 2 \\
\hline Serratia marcescens IFO3736 & 3 & 1.5 \\
\hline \multicolumn{3}{|l|}{ Polymyxin $\mathrm{B}^{\mathrm{b}}$} \\
\hline Escherichia coli JM109 & 3 & 0.3 \\
\hline Pseudomonas aeruginosa IFO3899 & 5 & 2.5 \\
\hline Salmonella typhimurium IFO13245 & 5 & 2.5 \\
\hline Serratia marcescens IFO3736 & 5 & 1 \\
\hline \multicolumn{3}{|l|}{ Nisin ${ }^{b}$} \\
\hline Staphylococcus aureus IFO12732 & 5 & 2 \\
\hline \multicolumn{3}{|l|}{ Indolicidin ${ }^{c}$} \\
\hline Staphylococcus aureus IFO12732 & 10 & 10 \\
\hline Escherichia coli JM109 & 10 & 10 \\
\hline \multicolumn{3}{|l|}{ Ampicillin ${ }^{c}$} \\
\hline Staphylococcus aureus IFO12732 & 250 & 250 \\
\hline \multicolumn{3}{|l|}{ Kanamycin $^{c}$} \\
\hline Staphylococcus aureus IFO12732 & 3 & 3 \\
\hline \multicolumn{3}{|l|}{ Enrofloxacin $^{c}$} \\
\hline Staphylococcus aureus IFO12732 & 0.25 & 0.25 \\
\hline
\end{tabular}

activity of bacterial membrane disruption by ASABF- $\alpha$. $\mathrm{diS} \mathrm{C}_{3}-(5)$ is a slow-response voltage-sensitive fluorescent dye [26]. The extracellularly administered diS- $\mathrm{C}_{3}$ (5) accumulates on the hyperpolarized cell membrane, translocates into the lipid bilayer, and redistributes between the cells and the medium in accordance with the membrane potential. Aggregation within the confined membrane interior or intracellular spaces usually results in reduced fluorescence by self-quenching. Depolarization or disruption of the cytoplasmic membrane causes the release of $\mathrm{diS}_{-} \mathrm{C}_{3}-(5)$ from the cells to the medium and an increase in fluorescence intensity. ASABF- $\alpha$ evoked the increase in fluorescence against $\mathrm{diS} \mathrm{C}_{3}$-(5)-loaded $S$. aureus IFO12732 in a dose-dependent manner (Figure 4A). ASABF- $\alpha$ induced calcein (molar mass $=622.53)$ leakage from the acidic-liposomes (data not shown), indicating that the increase in fluorescence was attributed to leakage of $\mathrm{diS}_{-} \mathrm{C}_{3}-(5)$ by membrane disruption rather than redistribution by depolarization. Bactercidal activity was parallel to the release of $\mathrm{diS}^{-\mathrm{C}_{3}-(5)}$ (Figure $4 \mathrm{~B}$ ), suggesting that
ASABF- $\alpha$ killed $S$. aureus mainly by disruption of the cytoplasmic membrane.

The effect of NP4P was investigated using this experimental setting. NP4P evoked no significant change in fluorescence at $\leq 10 \mu \mathrm{g} / \mathrm{mL}$ whereas weak ripples or limited increase were observed at higher concentrations ( $2.5 \%$ of maximal response at $100 \mu \mathrm{g} / \mathrm{mL}$ : the maximal response was defined as the increase in fluorescence at the plateau in the dose-response curve of ASABF- $\alpha$ ) (Figure 4C). In addition, NP4P did not disrupt the acidic-liposomal membrane at $\leq 220 \mu \mathrm{g} / \mathrm{mL}$ (data not shown). This suggests that NP4P barely affected either the membrane permeability or membrane potential of $S$. aureus. To test the effect of NP4P on the membranedisrupting activity of ASABF- $\alpha$, dose-response curves were determined in the presence or absence of NP4P (Figure 4D). The efficacy of membrane disruption by ASABF- $\alpha$ was remarkably enhanced by NP4P in a dosedependent manner. The threshold concentration of ASABF- $\alpha$ was not significantly affected. Several doses of NP4P were added to $S$. aureus which was intermediately damaged by $1.28 \mu \mathrm{g} / \mathrm{mL}$ of ASABF- $\alpha$ [36\% increase in maximal response in $\mathrm{diS}_{-} \mathrm{C}_{3}-(5)$ fluorescence] (Figure $4 \mathrm{E})$. Even $1 \mu \mathrm{g} / \mathrm{mL}$ of NP4P caused detectable enhancement. The degree of enhancement increased dosedependently. These results suggest that NP4P enhances the bactericidal activity of ASABF- $\alpha$ by increasing the efficacy of membrane disruption.

AMPs from the skin of a frog, PGLa and magainin 2, form heterodimers and show synergistic membrane disruption and antimicrobial activities [7,27]. NP4P is not as likely to bind directly with AMPs as PGLa and magainin 2 because the structure of ASABF- $\alpha$, nisin, and polymyxin $B$, whose bactericidal activities were enhanced by NP4P, are completely distinct [28-30]. NP4P is a highly basic molecule and could interact with negatively charged cytoplasmic membranes. A possible mechanism of NP4P enhancement is destabilization of the cytoplasmic membrane. Whereas NP4P did not exhibit neither growth inhibitory nor bactericidal activity against $S$. aureus at $\leq 200 \mu \mathrm{g} / \mathrm{ml}$, ripples or weak increase in diS- $_{3}-(5)$ fluorescence was evoked at $>10$ $\mu \mathrm{g} / \mathrm{mL}$, suggesting that NP4P interacted with bacterial cytoplasmic membranes and caused sublethal membrane destabilization. For acidic liposomes, NP4P neither evoked such membrane destabilization-like responses nor enhanced membrane disruption of ASABF- $\alpha$. However, the results obtained by quantifying bacterial membrane disruption using using diS- $\mathrm{C}_{3}-(5)$ may indicate the more specific mode of action. The intensities of enhancement did not correlate with the susceptibilities of the bacteria for the tested AMPs. The killing of $E$. coli JM109 was most efficiently enhanced for ASABF- $\alpha$ and polymyxin $B$, suggesting that the efficacy of NP4P 


\section{A}
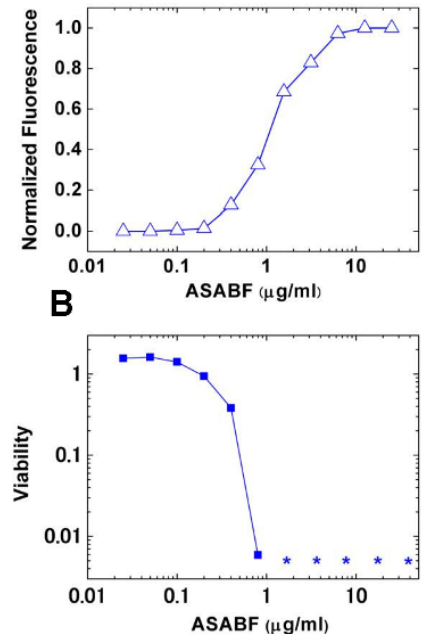

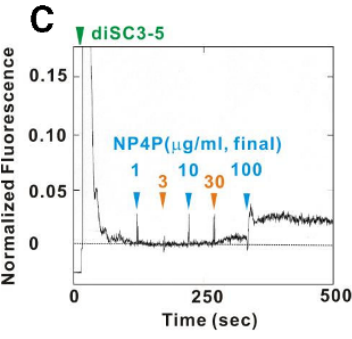

D

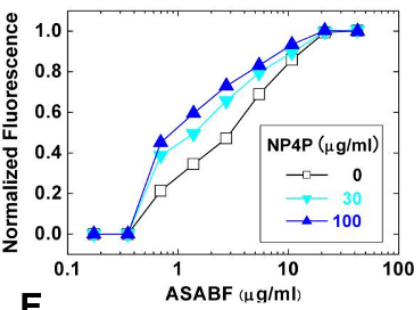

E

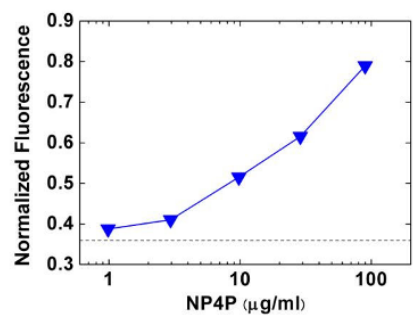

Figure 4 Effect of NP4P on the membrane-disrupting activity of ASABF- $\alpha$ against the cytoplasmic membrane of S. aureus. Disruption of the cytoplasmic membrane was estimated by the increase in fluorescence intensity of dis- $C_{3}-(5)$. Changes in fluorescence were normalized by the value at the plateau of the dose-response curves. (A) Dose-response curve and (B) dose-bactericidal effect curve of ASABF- $\alpha$ against S. aureus IFO12732. These curves were simultaneously determined. The asterisks indicate that viable cells were not detected. (C) Effect of NP4P on the cytoplasmic membrane. The time courses of fluorescence changes are represented. (D) Effect of NP4P on cytoplasmic membrane disruption by ASABF- $\alpha$. Dose-response curves were determined in the presence of NP4P at various concentrations $(0,30$, and $100 \mu \mathrm{g} / \mathrm{ml})$. (E) Another assay for NP4P enhancement. NP4P was applied after treatment of $1.28 \mu \mathrm{g} / \mathrm{mL}$ of ASABF- $\alpha$. The fluorescent change evoked only by ASABF- $\alpha$ is indicated by a dashed line.

enhancement depends on the species of bacteria rather than on that of AMPs. These results support our hypothesis that NP4P independently interacts with cytoplasmic membranes and not with AMPs. For acidic liposomes, membrane disruption of ASABF- $\alpha$ was inhibited in the presence of $20 \mu \mathrm{g} / \mathrm{mL}$ NP4P. The dose-response curve was shifted to a higher concentration $\left(\mathrm{IC}_{50}=0.23\right.$ $\mu \mathrm{g} / \mathrm{mL}$ without NP4P, and $0.53 \mu \mathrm{g} / \mathrm{ml}$ with NP4P), indicating that NP4P was a competitive inhibitor. This inhibition could be due to charge neutralization of the membrane surface by NP4P binding and prevention of ASABF- $\alpha$ binding in a similar manner to that observed between magainin 2 and an acyclic tachyplesin I analogue [16], i.e., NP4P and ASABF- $\alpha$ also bind to the liposomal membrane independently. This observation does not contradict our hypothesis mentioned above. The exact mechanisms for NP4P enhancement at the molecular level remains to be elucidated.

\section{Conclusions}

NP4P selectively enhances the bactericidal activities of membrane-disrupting AMPs (ASABF- $\alpha$, nisin, and polymyxin B). NP4P is not bactericidal and does not inhibit growth at $\leq 300 \mu \mathrm{g} / \mathrm{mL}$ against all tested bacteria, suggesting that the effect of NP4P is enhancement and is distinct from the previously reported synergy among AMPs and/or low-molecular mass antimicrobials [6-20]. Enhancement intensities depend on microbial species.
Relatively good enhancement was achieved for $S$. aureus and E. coli. Increasing the efficacy of membrane disruption against the bacterial cytoplasmic membrane may contribute to enhancement by NP4P.

AMPs are immune effectors against microbial infections in vertebrates, invertebrates, and plants. In humans, the deficiency in AMP functions often causes reduced resistance against infectious diseases [31,32], indicating that resistance may increase by enhancing the effect of AMPs. AMP-enhancers without antimicrobial activities are promising as immunopotentiators since they do not disturb the autonomic control of immunity. Although salt-inhibition remains to be resolved for practical use in mammals, NP4P is believed to be the first peptide which exerts AMP-enhancer activity.

\section{Methods}

\section{Microorganisms}

E. coli JM109 was purchased from Takara (Otsu, Japan). Other strains described below were transferred from the National Institute of Technology and Evaluation, Kazusa, Japan: S. aureus IFO12732, B. subtilis IFO3134, M. luteus IFO12708, P. aeruginosa IFO3899, S. typhimurium IFO13245 and S. marcescens IFO3736.

\section{Peptides and other AMPs}

NP4P, cecropin P4 and indolicidin were prepared at Biologica Co. (Nagoya, Japan). Briefly, peptides were 
synthesized by the Fmoc method, and purified by reversed-phase high-pressure liquid chromatography. The products were confirmed by time-of-flight mass spectrometry on a Voyager DE Mass Spectrometer, Applied Biosystems (Foster City, CA, USA). ASABF- $\alpha$ was prepared as previously described [24]. Some antimicrobials were purchased from Wako, Osaka, Japan (ampicillin, kanamycin, and polymyxin B); Sigma, St. Louis, MO, USA (nisin); and Bayer, Nordrhein-Westfalen, Germany (enrofloxacin).

\section{Growth assay}

Microbes in the mid-exponential phase were suspended in $2 \mathrm{~mL}$ of IFO702 medium (1\% polypeptone, $0.2 \%$ yeast extract, $0.1 \% \mathrm{MgSO}_{4} / 7 \mathrm{H}_{2} \mathrm{O}$ ) with or without NP4P. Their optical densities were adjusted to an $\mathrm{OD}_{600}$ of 0.06-0.08. The bacterial suspension was incubated at $30^{\circ} \mathrm{C}$. Bacterial growth was estimated by measuring the change in $\mathrm{OD}_{600}$.

Monkey Vero cells were grown in $2 \mathrm{ml}$ of Dulbecco's modified Eagle's medium supplemented with 5\% fetal bovine serum at $37^{\circ} \mathrm{C}$ and $5 \% \mathrm{CO}_{2}$. To estimate cytotoxicity, NP4P was added to the medium at $0,30,100$, and $300 \mu \mathrm{g} / \mathrm{mL}$. Cell proliferation and morphorogy were monitored for a week.

\section{Microbicidal assay}

Microbicidal assay was performed as previously described [33]. Briefly, each microbial strain in the midexponential phase was suspended in $10 \mathrm{mM}$ Tris/ $\mathrm{HCl}$, $\mathrm{pH}$ 7.5. The microbial suspension was mixed with antimicrobials in the presence or absense of NP4P. After $2 \mathrm{~h}$ incubation, the suspension was diluted 1,000 times and inoculated on to plates of IFO702 medium. The number of colonies were counted, and a plot of peptide concentration vs colony number was created.

\section{Liposome disruption assay}

Membrane-disrupting activity was estimated by liposome disruption assay [33]. A lipid film was prepared by rotary evaporation of lipid solution $[1 \mathrm{mg}$ lipid in $1 \mathrm{~mL}$ chloroform, phosphatidylglycerol (mole):caldiolipin $($ mole $)=3: 1]$. The lipid film was hydrated with $1 \mathrm{~mL}$ of $10 \mathrm{mM}$ Tris- $\mathrm{HCl}$ buffer (pH 7.5) containing $75 \mathrm{mM}$ calcein. Lipid dispersions were sonicated and subjected to five freeze-thaw cycles. Non-trapped calcein was removed by gel filtration on a Sephacryl S-300 spin column (GE Healthcare Bio-Science Corp., Piscataway, NJ, USA) equilibrated with $10 \mathrm{mM}$ Tris- $\mathrm{HCl}$ ( $\mathrm{pH} 7.5)$ containing $175 \mathrm{mM} \mathrm{NaCl}$ and $1 \mathrm{mM}$ EDTA. These calceinentrapped liposomes were diluted at a ratio of 1:1000 in $10 \mathrm{mM}$ Tris- $\mathrm{HCl}$ (pH 7.5) containing $350 \mathrm{mM}$ sucrose. Calcein release after membrane disruption was evaluated by measuring fluorescence intensity at $515 \mathrm{~nm}$ with excitation at $492 \mathrm{~nm}$ on a Shimadzu RF-5300PC spectrofluorometer (Shimadzu, Kyoto, Japan) at room temperature.

\section{Cytoplasmic membrane permeability assay}

Cytoplasmic membrane permeabilization of $S$. aureus was determined with a voltage-sensitive dye, $\mathrm{diS}^{-\mathrm{C}_{3}-(5)}$ $[34,35]$. Bacteria in the mid-exponential phase were suspended in $10 \mathrm{mM}$ Tris- $\mathrm{HCl}$ with or without NP4P, $\mathrm{pH}$ 7.5 to an $\mathrm{OD}_{600}$ of 0.05 . Changes in fluorescence were continuously monitored using a Shimadzu RF-5300PC spectrofluorometer at an excitation wavelength of $622 \mathrm{~nm}$ and an emission wavelength of $670 \mathrm{~nm}$. The bacterial suspension was incubated with $400 \mathrm{nM}$ diS- $\mathrm{C}_{3}$ (5). ASABF- $\alpha$ was added to the bacterial suspension after the dye uptake was maximal. The maximal increase in fluorescence due to disruption of the cytoplasmic membrane was recorded.

\section{Acknowledgements}

This work was partly supported by research fellowships of the Japan Society for the Promotion of Science for Young Scientists (to SU).

\section{Author details}

${ }^{1}$ Division of Insect Sciences, National Institute of Agrobiological Sciences, Oowashi 1-2, Tsukuba, Ibaraki 305-8634, Japan. ${ }^{2}$ Graduate School of Life and Environmental Sciences, University of Tsukuba, Tennoudai 1-1-1, Tsukuba, Ibaraki 305-8572, Japan.

\section{Authors' contributions}

SU, KK, and YK designed and performed most of the experimental work. SU and $Y T$ performed the experiment using liposomes. MM and $\mathrm{HZ}$ has mainly performed the antimicrobial assay. YK edited the manuscript. This study conducted completely under the supervision of YK. All authors read and approved the final manuscript.

Received: 30 June 2009

Accepted: 15 February 2010 Published: 15 February 2010

\section{References}

1. Brogden KA: Antimicrobial peptides: pore formers or metabolic inhibitors in bacteria?. Nat Rev Microbiol 2005, 3:238-250.

2. 21 CFR Ch.I (4-1-03 Edition) Food and Drug Administration, HHS.\$184.1538. 2003.

3. Landman D, Georgescu C, Martin DA, Quale J: Polymyxins revisited. Clin Microbiol Rev 2008, 21:449-465.

4. Hancock REW, Sahl HG: Antimicrobial and host-defense peptides as new anti-infective therapeutic strategies. Nat Biotechnol 2006, 24:1151-1157.

5. Subbalakshimi C, Sitaram N: Mechanism of antimicrobial action of indolicidin. FEMS Microbiol Lett 1998, 160:91-96.

6. Giacometti A, Cirioni O, Riva A, Kamysz W, Silvestri C, Nadolski P, Della Vittoria A, Łkasiak J, Scalise G: In vitro activity of aurein 1.2 alone and in combination with antibiotics against gram-positive nosocomial cocci. Antimicrob Agents Chemother 2007, 51:1494-1496.

7. Westerhoff HV, Zasloff M, Rosner JL, Hendler W, De Waal A, Vaz Gomes A, Jongsma PM, Riethorst A, Juretić D: Functional synergism of the magainins PGLa and magainin-2 in Escherichia coli, tumor cells and liposomes. Eur J Biochem 1995, 228:257-264.

8. Mor A, Hani K, Nicolas P: The vertebrate peptide antibiotics dermaseptins have overlapping structural features but target specific microorganisms. J Biol Chem 1994, 269:31635-31641.

9. Rosenfeld $Y$, Barra D, Simmaco M, Shai Y, Mangoni ML: A synergism between temporins toward Gram-negative bacteria overcomes 
resistance imposed by the lipopolysaccharide protective layer. $J$ Biol Chem 2006, 281:28565-28574.

10. Nagaoka I, Hirota S, Yomogida S, Ohwada A, Hirata M: Synergistic actions of antibacterial neutrophil defensins and cathelicidins. Inflamm Res 2000, 49:73-79.

11. Levy O, Ooi CE, Weiss J, Lehrer RL, Elsbach P: Individual and synergistic effects of rabbit granulocyte proteins on Escherichia coli. J Clin Investig 1994, 94:672-682.

12. Lauth X, Babon JJ, Stannard JA, Singh S, Nizet V, Carlberg JM, Ostland VE, Pennington MW, Norton RS, Westerman ME: Bass hepcidin synthesis, solution structure, antimicrobial activities and synergism, and in vivo hepatic response to bacterial infections. J Biol Chem 2005, 280:9272-9282.

13. Gueguen Y, Romestand B, Fievet J, Schmitt P, Destoumieux-Garzón D, Vandenbulcke $F$, Bulet $P$, Bachère $E$ : Oyster hemocytes express a prolinerich peptide displaying synergistic antimicrobial activity with a defensin. Mol Immunol 2009, 46:516-522.

14. lijima R, Kurata S, Natori S: Purification, characterization, and cDNA cloning of an antifungal protein from the hemolymph of Sarcophaga peregrina (flesh fly) larvae. J Biol Chem 1993, 268:12055-12061.

15. Lüders T, Birkemo GA, Fimland G, Nissen-Meyer J, Nes IF: Strong synergy between a eukaryotic antimicrobial peptide and bacteriocins from lactic acid bacteria. Appl Environ Microbiol 2003, 69:1797-1799.

16. Kobayashi S, Hirakura Y, Matsuzaki K: Bacteria-selective synergism between the antimicrobial peptides alpha-helical magainin 2 and cyclic betasheet tachyplesin I: toward cocktail therapy. Biochemistry 2001, 40:14330-14335.

17. Chalk R, Albuquerque CM, Ham PJ, Townson H: Full sequence and characterization of two insect defensins: immune peptides from the mosquito Aedes aegypti. Proc Biol Sci 1995, 261:217-221.

18. Yan H, Hancock REW: Synergistic interactions between mammalian antimicrobial defense peptides. Antimicrob Agents Chemother 2001, 45:1558-1560

19. Polak J, Della Latta P, Blackburn P: In vitro activity of recombinant lysostaphin-antibiotic combinations toward methicillin-resistant Staphylococcus aureus. Diagn Microbiol Infect Dis 1993, 17:265-270.

20. Graham S, Coote PJ: Potent, synergistic inhibition of Staphylococcus aureus upon exposure to a combination of the endopeptidase lysostaphin and the cationic peptide ranalexin. J Antimicrob Chemother 2007, 59:759-762.

21. Pillai A, Ueno S, Zhang H, Lee JM, Kato Y: Cecropin P1 and novel nematode cecropins: a bacteria-inducible antimicrobial peptide family in the nematode Ascaris suum. Biochem J 2005, 390:207-214.

22. Ueno S, Kusaka K, Tamada Y, Minaba M, Zhang H, Wang PC, Kato Y: Anionic C-terminal proregion of nematode antimicrobial peptide cecropin $\mathrm{P} 4$ precursor inhibits antimicrobial activity of the mature peptide. Biosci Biotechnol Biochem 2008, 72:3281-3284.

23. Kato Y, Komatsu S: ASABF, a novel cysteine-rich antibacterial peptide isolated from the nematode Ascaris suum: purification, primary structure, and molecular cloning of cDNA. J Biol Chem 1996, 271:30493-30498.

24. Zhang H, Yoshida S, Aizawa T, Murakami R, Suzuki M, Koganezawa N, Masuura A, Miyazawa M, Kawano K, Nitta K, Kato Y: In vitro antimicrobial properties of recombinant $\mathrm{ASABF}$, an antimicrobial peptide isolated from the nematode Ascaris suum. Antimicrob Agents Chemother 2000, 44:2701-2705.

25. Pillai A, Ueno $S$, Zhang $H$, Kato $Y$ : Induction of ASABF (Ascaris suum antibacterial factor)-type antimicrobial peptides by bacterial injection: novel members of ASABF in the nematode Ascaris suum. Biochem J 2003, 371:663-668.

26. Sims PJ, Waggoner AS, Wang CH, Hoffman JF: Studies on the mechanism by which cyanine dyes measure membrane potential in red blood cells and phosphatidylcholine vesicles. Biochemistry 1974, 13:3315-3329.

27. Matsuzaki K, Mitani Y, Akada KY, Murase O, Yoneyama S, Zasloff M, Miyajima K: Mechanism of synergism between antimicrobial peptides magainin 2 and PGLa. Biochemistry 1998, 37:15144-15153.

28. Aizawa T, Hoshino H, Fujitani N, Koganesawa N, Matsuura A, Miyazawa M, Kato Y, Kumaki Y, Demura M, Nitta K, Kawano K: Structural analysis of an antibacterial peptide derived from a nematode. Peptide Science 2000 The Japanese Peptide SocietyShioiri T 2001, 269-272.

29. Van den Hooven HW, Doeland CC, Van De Kamp M, Konings RN, Hilbers CW, Van De Ven FJ: Three-dimensional structure of the lantibiotic nisin in the presence of membrane-mimetic micelles of dodecylphosphocholine and of sodium dodecylsulphate. Eur J Biochem 1996, 235:394-403.

30. Chapman TM, Golden MR: Polymyxin B. NMR evidence for a peptide antibiotic with folded structure in water. Biochem Biophys Res Commun 1972, 46:2040-2047.

31. Smith JJ, Travis SM, Greenberg EP, Welsh MJ: Cystic fibrosis airway epithelia fail to kill bacteria because of abnormal airway surface fluid. Cell 1996, 85:229-236.

32. Pütsep K, Carlsson G, Boman HG, Andersson M: Deficiency of antibacterial peptides in patients with morbus Kostmann: an observation study. Lancet 2002, 360:1144-1149.

33. Zhang H, Morikawa K, Ohta T, Kato Y: In vitro resistance to the CS $\alpha \beta$-type antimicrobial peptide ASABF- $\alpha$ is conferred by overexpression of sigma factor sigB in Staphylococcus aureus. J Antimicrob Chemother 2005, 55:686-691.

34. Weinstein JN, Yoshikami S, Henkart P, Blumenthal R, Hagins WA: Liposomecell interaction: transfer and intracellular release of a trapped fluorescent marker. Science 1977, 195:489-491.

35. Friedrich CL, Moyles D, Beveridge TJ, Hancock REW: Antibacterial action of structurally diverse cationic peptides on Gram-positive bacteria. Antimicrob Agents Chemother 2000, 44:2086-2092.

doi:10.1186/1471-2180-10-46

Cite this article as: Ueno et al:: An enhancer peptide for membranedisrupting antimicrobial peptides. BMC Microbiology 2010 10:46.

\section{Submit your next manuscript to BioMed Central and take full advantage of:}

- Convenient online submission

- Thorough peer review

- No space constraints or color figure charges

- Immediate publication on acceptance

- Inclusion in PubMed, CAS, Scopus and Google Scholar

- Research which is freely available for redistribution
Ciomed Central 